Mallett O \& Wapshott R (2017) Small business revivalism: employment relations in small and medium-sized enterprises, Work, Employment and Society, 31 (4), pp. 721728. Copyright The Authors 2017. Reprinted by permission of SAGE Publications.

\title{
Small business revivalism: employment relations in small and medium-sized enterprises
}

Oliver Mallett (Newcastle University) and Robert Wapshott (Sheffield University)

\begin{abstract}
This e-special issue focuses on employment relations in the context of 'small business revivalism' and an 'enterprise culture' that has sought to establish a so-called 'entrepreneurial economy' (Parker, 2011). Economic restructuring and other political, social and economic changes in the 1970s and 1980s led to an increase in the number and prominence of small and medium-sized enterprises, with implications for the working lives of many people who are now more likely to work as self-employed, freelancers or members of smaller organisations. This e-special issue presents research from Work, Employment and Society that considers important elements of these changes including debates about the influences of businesses' external and internal environments, family relations and government policy. This introduction provides a general overview of the field of employment relations in small and medium-sized enterprises and the 11 articles included in the e-special issue.
\end{abstract}

\section{Key words}

Employment relations; family business; policy; small and medium-sized enterprises

Corresponding author: Oliver Mallett, Newcastle University Business School, 5 Barrack Road, Newcastle Upon Tyne, NE1 4SE, oliver.mallett@ncl.ac.uk 
The years surrounding the launch of Work, Employment and Society in 1987 saw changes in the nature of work and employment relations for many people, with significant increases in self-employment and small business ownership (Burrows and Curran, 1989). ONS figures indicate that around $15.6 \mathrm{~m}$ jobs, or 60 percent of private sector employment, in the UK are now accounted for by small and medium-sized enterprises (SMEs, defined as having 0-249 employees, BIS, 2015). These businesses are therefore invaluable sites for understanding the changing nature of work and employment. This e-special issue explores the key research areas that have emerged in Work, Employment and Society relating to debates around the influence of external and internal factors on shaping employment relations, the relevance of family and the implications of government policy. Here we introduce the general topic in relation to the specific contribution of the 11 articles chosen for inclusion.

\section{Small business revival}

In the UK, the recessions of the 1970s and 1980s were influential in a restructuring of the economy, creating a reversal in prior trends towards consolidation of large businesses. As large firms decreased the size of their operations they created more opportunities for SMEs as they fragmented their operations through decentralisation (e.g. more small plants), devolvement (e.g. franchising) and disintegration (e.g. subcontracting) (Shutt and Whittington, 1987; Curran, 1990). This represented a transfer of jobs from large organisations to SMEs. Further, as large firms withdrew from some areas of business due to tough conditions and manufacturing began to account for less employment as the service sector became more important, niches emerged in which SMEs could operate. The flexibility associated with SMEs has been presented as key to their greater prominence in such restructured economies, 
[Type here]

flexibility in terms of their roles in supply chains and in providing specialisation (Burrows and Curran, 1989).

The increase of SMEs, demands for flexibility and the responses to competitive and often challenging operating environments contributed to changes in employment relations for large numbers of workers and this became an important area of study. These changes must be understood in relation to SMEs' relatively high failure rates and potentially poorer working conditions (Parker, 2001), as may be suggested in part by small businesses' poor record at employment tribunals (Saridakis et al., 2008). The sociological perspective on employment relations in SMEs has generated valuable insights into these changes (Edwards, 1995, for example, notes the particular role of Work, Employment and Society in these debates) and it is this perspective that is drawn out in this e-special issue.

\section{Size is not everything}

Focusing on business size, in and of itself, risks a danger that '...the heterogeneity of the small firm is subsumed into a monocausal explanation of shared industrial relations characteristics' (Rainnie, 1991: 182). Curran (1990: 129) has gone further to suggest that 'Size is not a very interesting or important attribute of an economic unit sociologically when set alongside others such as economic sector, technology, locality, labour and product markets, etc.' Nonetheless, as Curran acknowledges, business size is likely to affect these other factors.

While being alert to the unhelpful homogenising effect of catch-all terms such as SME, there is a long tradition of research that has gradually developed more complex characterisations, many of which derive from the constraints these businesses face (Curran, 2006). These include constrained resources and a relative inability to 
influence their operating environment, albeit that the differences from large businesses tend to be 'a matter of degree not kind' (Ram et al., 2001: 846). In compiling this e-special issue we have taken a broad approach to SMEs in an attempt to draw out interesting insights from a range of articles that relate to employment relations issues that may be missing from more familiar large business settings.

Importantly, these nuanced and critical representations of employment relations in SMEs have questioned earlier representations of these organisations as sites of unfailingly progressive employment practices, high job satisfaction and low rates of dispute. It had been assumed that 'small is beautiful', contrasting small and large businesses in terms of closer working relationships, flexibility, role variety and opportunities for personal development, suggesting that these advantages off-set the lower rates of pay found in SMEs (Bolton, 1971). These descriptions of SMEs were seen as accounting for low rates of trade union participation but overlooked the alternative ways, beyond strikes and formal industrial action, that discontent and conflict may manifest in the workplace (Rainnie, 1991). To understand the development of a richer picture of employment relations in SMEs, it is necessary to place SMEs within a broader context.

\section{Supply chains and SME dependency}

As large businesses responded to financial crises through the 1970s and 1980s, shedding non-core activities such as cleaning or catering and developing external supply chains, this created opportunities for SMEs but also new challenges (Curran, 1990). Such changes, for example, had the potential to benefit SMEs through the development of long term relationships, creating a degree of security and providing opportunities for training, technology transfer and the sharing of best practice. However, Rainnie (1991: 365), in this e-special issue, argues that large businesses 
[Type here]

tend to prefer large sub-contractors, leaving SMEs as sub-sub-contractors 'picking up the crumbs from the large sub-contractor's table'.

Such arrangements involve the transfer of risk to the smaller businesses in the supply chain which are also less likely to be able to manage such risks, while the larger businesses ensure SMEs meet their requirements through 'exhortation, example, threat and tight control' (p.364). This understanding of supply chains relates to Rainnie's conceptualisation of the difference between SMEs dependent on large businesses (e.g. sub-contractors) and those relatively independent, either because they compete through the hyper-exploitation of labour or because they operate in specialist niches (developing Shutt and Whittington, 1987). Rainnie argues that, in these ways, the external environment can constrain both traditional ideas of independence and owner-manager prerogative as well as the scope for employees to contest the ways they are managed or negotiate better working conditions.

While providing invaluable insights, Rainnie's analysis has been criticised for being overly-deterministic and failing to attend to how these external factors influence employment relations within SMEs in sufficient detail (Curran, 1990). Ownermanager prerogative, for example, may still be important in influencing how the external influences are interpreted or managed within the business (Wapshott and Mallett, 2015).

\section{Looking inside SMEs}

Ram (1991), included in this e-special issue, studied manufacturing businesses that were not tied to large businesses but sold through intermediaries. These SMEs were operating in very difficult competitive conditions but Ram nonetheless identified space for internal conflict and negotiation. For example, where staff were paid for 
garments not time, breaks, holidays and slower working were accepted by the employers because they lowered the workers' pay. Ram suggests that this ongoing negotiation persists despite the businesses operating in highly competitive markets because of shortages of suitably skilled labour, specifically of cheap immigrant labour, and a concern that, when demand levels increase, owner-managers will need staff on hand to fill these orders.

Ram makes sense of this in terms of a 'negotiated order' which derives from complicated, often contradictory processes relating to, for example, the informal, contingent ways in which piece-rates were fixed. These piece-rates were variably applied and up for renegotiation, which took place in the structural context of employer/employee antagonism and necessary interdependence. The negotiations that result allow for the different interests to be more or less accommodated, creating idiosyncratic and potentially complex arrangements. In this way, while acknowledging the influence of external factors, Ram demonstrates how these are interpreted and applied through processes of conflict and cooperation internal to the business.

In-depth research such as Moule's (1998) participant observation at a small manufacturing business, included in this e-special issue, provides a rich exploration of many of these issues. Moule reports that the powerful influence of large businesses (even if at one remove in the supply chain) imposed particular requirements, especially in terms of turnaround times. However, while this impacted on the shopfloor, 'it did so not in a static way which implies the imposition of control, but through a dynamic (socio-political) process which rendered control a more fluid outcome' (p.642). For example, focusing on the day-to-day dynamics on the shopfloor, where he gained contextualised access to employee voices, Moule explores 
[Type here]

employee negotiation and resistance and reveals how the external influences created greater dependence on certain workers. With dyehouse workers playing a more important role in meeting client demands for volume, quality and delivery time than despatchers, they had greater scope for rule bending as part of the employment relations prevailing in that part of the business. The dynamism of employment relations is therefore shaped by both internal interactions and external influences.

\section{Debating an integrated approach}

These varying emphases on external and internal areas of influence and negotiation of employment relations in SMEs have been notably debated in Work, Employment and Society through the frank exchange between Barrett and Rainnie (2002) and Ram and Edwards (2003). Barrett and Rainnie (2002) set out a broad critique of studies of employment relations in SMEs as homogenising these businesses and failing to provide analytical tools with which to understand them. In response to these perceived limitations, Barrett and Rainnie propose a dialectical approach which, instead of treating businesses in isolation, engages with totality, change and contradiction in order to make sense of the dynamic relations between large businesses and SMEs. In doing so it returns to and refines Rainnie's earlier typology.

Ram and Edwards (2003) argue that Barrett and Rainnie 'overstate their contribution, while underplaying that of more recent research to the field' (p.719). For Ram and Edwards, in contrast to Rainnie's framework which had lacked empirical testing, research looking at employee experiences of the employment relationship in SMEs has been much stronger than Barrett and Rainnie's analysis allowed. For example, they suggest that research has produced some valuable explorations of employee voices and actions. They suggest that this research, including contributions featured in 
this e-special issue, has provided important insights and further developed our understanding of the dialectical relationship Barrett and Rainnie highlight.

\section{Family relations and SMEs}

An important theme of Ram and Edwards's critique of Barrett and Rainnie concerns the importance of family relations in many SMEs; an area that has received several insightful treatments in the pages of Work, Employment and Society. Dick and Morgan (1987) highlight several relevant areas in the literature: the division of labour within families extended to the workplace, the family as a form of self-control by workers, family ideology deployed by employers and the importance of kinship ties in what can be considered access to extended internal labour markets.

Dick and Morgan researched a textile mill in West Yorkshire (UK), originally a one man business but now part of a multinational company. The extensive family networks Dick and Morgan identify within the business stretch back through multiple generations and provide a means not only of recruitment but also of managing different types of work through stages of the life cycle, most clearly seen through the complex patterns of employment for women. It also related to providing advice and support for members within the family network, constituting a part of the informality running through the employment relationship. While Dick and Morgan's work is not a study of an SME it does highlight family-related issues of importance to the rising numbers of SMEs and to the study of these businesses, leading to its citation in several important contributions.

The influence of family acts as both resource and constraint, providing flexibility (greater trust and forms of control) but also obligations (an inability to fire ineffective staff). This highlights informality in the employment relations of SMEs as seen in Ram (1991) where employees' families were brought in to help settle disputes with 
[Type here]

management. Grugulis et al.'s (2000) in-depth study of a medium-sized consultancy business, included in this e-special issue, expands on this by demonstrating the use of organisational culture as a means of normative control. The authors identify a balance between freedom, in this case autonomy and freedom from bureaucracy, and forms of control extending beyond work to include social activities and the types of people who were said to belong in the company.

Baines and Wheelock (1998), also in this e-special issue, deploy a household level of analysis to understand working practices in micro businesses in terms of the reembedding of the family in economic institutions. They highlight the commodified relations in the home, with businesses being run by spouses, either paid or unpaid, and with tasks divided along traditional gender lines. Overall, the approach taken by Baines and Wheelock leads them to characterise the employment relations as difficult and chaotic, leaving many owner-managers wary of employing people or pursuing employment growth.

\section{Policy-making}

Politically, this complexity has been largely elided as SMEs became 'entrusted with part of the burden of resuscitating the crisis wracked British economy' (Rainnie, 1985: 143). SMEs have been deployed by a range of different political agendas, for example, in the UK, from the individualism of Thatcher to the New Labour agenda of inclusion and social justice. Politically, SMEs have therefore become viewed as central to Britain's knowledge-based, liberal market economy; improving the dynamism of economies by increasing market entry and innovation; producing a more equal spread of economic benefits; improving competition; and tackling unemployment (Bennett, 2008). Challenges to this rationale, and the problematic 
evidence base used to support it, have not limited its influence on successive governments in the UK and elsewhere (Bennett, 2008; Bridge, 2010).

The article in this e-special issue by Parker (2001) identifies a continuing romanticisation of SMEs in policy-making. This leads to suggestions of exemptions for SMEs, for example from particular employment regulations (Beecroft, 2011), as a means of 'freeing them' to innovate and compete. However, after reviewing the international evidence, Parker concludes that 'small enterprises cannot be regarded as superior to large firms in any general sense because most small firms are not innovative, do not contribute to employment growth and do not engage in progressive employment practices' (p.374). She therefore suggests that there is little justification for promoting businesses of a particular size.

Hoque and Bacon (2006), also included in this e-special issue, use the 1998 Workplace Employment Relations Study (WERS) survey to examine training in SMEs. They highlight this as an important area linked to relatively low productivity growth and performance and therefore a focus for policy initiatives. For example, the UK government initiative Investors in People (IiP) started out as a means of recognising businesses that invested in particular types of staff training and development. The accreditation has been viewed as sufficiently successful to expand its scope to a more general 'high performance' agenda and become something that large businesses might insist on from their suppliers or sub-contractors. However, Hoque and Bacon (2006) found little impact of IiP accreditation on SME training activity, the WERS data indicating similar levels of training activity for SMEs with IiP accreditation as those without. Likewise, the research included in this e-special issue is suggestive of the need for a much more nuanced understanding of SMEs by policy-makers who seek to support them. 
[Type here]

\section{Conclusion}

In this e-special issue we have drawn together 11 of the most relevant and insightful Work, Employment and Society articles to understanding employment relations in SMEs. These articles provide an historical and theoretical scope to the key debates in this area and suggest avenues for further exploration to progress this tradition. The extent to which considerations such as sub-contracting arrangements exert influence on businesses and give rise to negotiated responses that shape their employment relations helps us to understand what might underlie the practices in use.

Post-financial crisis (and potentially post-Brexit), economic challenges and restructuring are again likely to place emphasis on SMEs with significant implications for employment relations. For example, as businesses like Amazon or Uber attempt to classify their employees as self-employed (Fuchs, 2016), moving the relationship from a contract of service to a contract for services, it is vital to understand the changing nature of employment relations and the conditions of modern employment.

We cannot start getting to grips with understanding employment relations and practices in businesses unless we have some appreciation of how they sit in relation to the various influences in these businesses' environments and the particular processes by which internal negotiations develop within them. If, as occurs in some areas of the SME literature, we are continually comparing the practices we find against a supposed ideal of 'best practice', the temptation is to identify only those practices that can fit into a given frame of reference rather than seeking out practices in use, understanding what they are intended to achieve, how they are negotiated and with what results. It is a research agenda developed in relation to the latter set of questions that would continue to develop our understanding about employment relations in SMEs. This is an important aim because, as this introduction has sought to highlight, 
employment relations are changing as the prominence of SMEs grows, with implications for political, economic and social questions and for areas such as industrial disputes, the family and the nature of work.

\section{References}

Baines S and Wheelock J (1998) Reinventing traditional solutions: job creation, gender and the micro-business household. Work, Employment and Society 12(4): 579601 .

Barrett R and Rainnie A (2002) What's so special about small firms? Developing an integrated approach to analysing small firm industrial relations. Work, Employment and Society 16(3): 415-431.

Beecroft A (2011) Report on employment law. Available at: https://www.gov.uk/government/uploads/system/uploads/attachment_data/file/31583/ 12-825-report-on-employment-law-beecroft.pdf accessed 30/08/2016.

Bennett R (2008) SME policy support in Britain since the 1990s: what have we learnt? Environment and Planning C: Government and Policy 26(2): 375-397.

BIS (2015) Business population estimates for the UK and regions 2015. Available at: https://www.gov.uk/government/uploads/system/uploads/attachment_data/file/467443 lbpe_2015_statistical_release.pdf

Bolton JE (1971) Small Firms: Report of the Committee of Inquiry on Small Firms. London: HMSO. Cmnd. 4811.

Bridge S (2010) Rethinking Enterprise Policy. Palgrave: Basingstoke.

Burrows R and Curran J (1989) Sociological research on service sector small businesses: some conceptual considerations. Work, Employment and Society 3(4): 527-539.

Curran J (1990) Rethinking economic structure: exploring the role of the small firm and self-employment in the British economy. Work, Employment and Society 4(5): 125-146.

Curran J (2006) 'Specificity' and 'Denaturing' the Small Business. International Small Business Journal 24(2): 205-210.

Dick B and Morgan G (1987) Family Networks and Employment in Textiles. Work, Employment and Society 1(2): 225-46.

Edwards PK (1995) From industrial relations to the employment relationship: the development of research in Britain. Industrial Relations 50(1): 39-65. 
[Type here]

Fuchs C (2016) Legal struggles in the age of uber-capitalism: are uber-drivers workers or self-employed? Available at: http://www.huffingtonpost.co.uk/christianfuchs1/legal-struggles-in-the-ag_b_12720298.html

Grugulis I, Dundon T and Wilkinson A (2000) Cultural control and the 'culture manager': employment practices in a consultancy. Work, Employment and Society 14(1): 97-116.

Hoque K and Bacon N (2006) The antecedents of training activity in British small and medium-sized enterprises. Work, Employment and Society 20(3): 531-552.

Moule C (1998) The Regulation of Work in Small Firms. Work, Employment and Society 12(4): 635-54.

Parker R (2001) The myth of the entrepreneurial economy: employment and innovation in small firms. Work, Employment and Society 15(2), 373-384.

Rainnie A (1985) Small firms, big problems: the political economy of small businesses. Capital and Class 9: 140-168.

Rainnie A (1991) Just-in-time, sub-contracting and the small firm. Work, Employment and Society 5(3): 353-375.

Ram M (1991) Control and Autonomy in Small Firms. Work, Employment and Society 5(4): 601-19.

Ram M, Edwards P, Gilman M and Arrowsmith J (2001) The dynamics of informality: employment relations in small firms and the effects of regulatory change. Work, Employment and Society 15(4): 845-861.

Ram M and Edwards P (2003) Praising Caesar not burying him: what we know about employment relations in small firms. Work, Employment and Society 17(4): 719-730.

Saridakis G, Sen-Gupta S, Edwards P and Storey DJ (2008) The impact of enterprise size on employment tribunal incidence and outcomes: evidence from Britain. British Journal of Industrial Relations 46(3): 469-499.

Shutt J and Whittington R (1987) Fragmentation strategies and the rise of small units: cases from the North West. Regional Studies 21(1): 13-23.

Wapshott R and Mallett O (2015) Managing Human Resources in Small and Mediumsized Enterprises: Entrepreneurship and the Employment Relationship. Abingdon: Routledge.

Oliver Mallett is a Senior Lecturer in Organisational Behaviour at Newcastle University Business School. His research focuses on informality and employment relationships in small firms and he is currently undertaking a project exploring the interactions between different forms of formal and informal support for small businesses. 
Robert Wapshott is a Senior Lecturer in Entrepreneurship at Sheffield University Management School. His main research interests include the employment relationships of SMEs and issues of diversity in entrepreneurship and selfemployment. Currently he is researching cross-border entrepreneurship education programmes. 